\title{
NÄETKÖ SATEENKAARTEN VÄRIT? Pervon yhteenkuulumisen affektiiviset politiikat
}

\author{
Tuula Juvonen ja Marjo Kolehmainen
}

Länsimaissa on viime vuosina käyty kiivasta keskustelua samaa sukupuolta olevien kumppanien avioliittojen statuksesta ja muista ihmisoikeuskysymyksistä. Tässä suhteessa Suomi ei muodosta poikkeusta, sillä eduskunta hyväksyi vuonna 2014 yhdenvertaisen avioliittolain ja sen myötä adoptiooikeuden. Ennen lain hyväksymistä käydyt kiivaat keskustelut pari- ja sukulaisuussuhteista osoittavat, kuinka affektiivisesti merkittäviä kuulumisen politiikat ovat (Juvonen 2015). Affektiivisesta ulottuvuudesta huolimatta, tai juuri siitä johtuen, kuulumisen käsitettä harvoin kyseenalaistetaan, sillä tavallisimmin huomio kiinnitetään siihen, mihin ja milloin mukaan ottamisen tai ulossulkemisen rajat tulisi vetää. Esimerkiksi Suomessa kiista kuulumisesta jatkuu yhdenvertaisen avioliittolain voimaanastumisen jälkeenkin, kun nyt taistellaan oikeudesta kirkolliseen vihkimiseen.

Vaikka monien mielestä lakimuutokset ovat tervetulleita merkkejä yhteiskunnan muuttumisesta yhdenvertaisemmaksi, seksuaalivähemmistöjen - etenkin lesbojen ja homojen - assimilaatiota on myös kritisoitu homonormatiivisuudesta. Kritiikki kohdistuu esimerkiksi senkaltaiseen parisuhdenormatiivisuuteen, jossa parikeskeisyyden ylittävät sosiaalisen sitoutumisen muodot ohitetaan. Tämänkaltainen avioliiton ja assimilationististen tavoitteiden kritiikki osoittaa, että kuulumisen ideaa(lia) voi myös "outouttaa". Näin ollen voidaan ajatella, että yksi queer-tutkimuksen vahvuus on siinä, että sen avulla on mahdollista laajentaa keskustelua tutuista seksuaalivähemmistöjen oikeuksia koskevista diskursseista tätä laajempiin mukaan ottamisen tai ulossulkemisen kysymyksiin.

Queer-yhteisössä kuulumisen kysymykset tulevat esiin lyhenteiden käyttöä koskevissa muutoksissa. Aiemmin käytössä ollut LHBT on muuttunut LHBTI:ksi, ja sittemmin monet ovat alkaneet käyttää lyhennettä LHBTIQA+, jossa plusmerkki ilmaisee pyrkimystä yhä laajempaan kattavuuteen. Jää kuitenkin nähtäväksi, missä määrin kuulumista itseään voi kyseenalaistaa, ja mitä seurauksia sillä olisi pervopolitiikalle tai -tutkimukselle. Miltei poikkeuksetta kuuluminen nähdään myönteiseksi ja tavoiteltavaksi asiantilaksi (Lähdesmäki ym. 2016). Queer-teorian ja affektiteorian risteyskohdissa assimilaation ja abjektion dualismeja on kuitenkin myös kyetty haastamaan, mikä on avannut mahdollisuuksia myös kuulumattomuuden kriittiselle tarkastelulle (Liu 2017).

Suomen queer-tutkimusseuran julkaiseman SQS-lehden kymmenvuotisnumero muistuttaa lukijoita siitä, että kuulumisen käsitteen käyttöala on queer-tutkimuksessakin laajempi kuin vain "normatiivisen heterosek- 
suaalisuuden" ja "ei-normatiivisten seksuaalisuuksien" välisen suhteen tarkastelussa. Vaikka eittämättä on tarpeen tarkastella avioliittolakien ja adoptio-oikeuden kaltaisia epäoikeudenmukaisuuksien paikkoja, perhekeskeisyyteen painottuvat diskurssit ja politiikat helposti peittävät näkyvistä sellaisten yhteisöllisyyden muotojen tarkastelun, jotka ulottuvat parisuhteen ja reproduktiivisen perheen kaltaisten helpoimmin tunnistettavien ja arvostettujen sosiaalisen sitoutumisen muotojen tuolle puolen. Sen lisäksi tämä numero pyrkii osoittamaan, kuinka affektiiviset ulottuvuudet ovat aina läsnä silloin, kun tutkimuksen kohteena on halu kuulua johonkin (Lähdesmäki ym. 2016). Affektiivisuuden tarkastelu tarjoaa hedelmällisiä välineitä niin kuulumisen ja kuulumattomuuden kuin niihin liittyvien eriarvoisuuksien ja epäsymmetrioiden tunnistamiseen ja tutkimiseen. Sillä siinä missä affektit merkitsevät niin yhteenkuuluvuutta kuin -kuulumattomuuttakin, ne eivät ainoastaan tuo meitä yhteen, intentioistamme riippumatta, vaan myös pakottavat meitä erilleen, tai osoittavat tosiasiallisten subjektien välisen yhteyden puuttumisen. (Hemmings 2012; Seigworth ja Gregg 2010.) Tämän numeron teksteistä useat nostavat esiin sellaisen affektiivisen kuulumisen yhteisöllisiä muotoja, jotka ovat jääneet vaille muodollista tunnustusta.

\section{Intersektionaaliset mukaan ottamiset ja ulossulkemiset}

Kuuluminen ei ole merkittävää vain eri ryhmien väliselle suhteelle, vaan myös ryhmien sisäisille suhteille. Näin ollen mukaan ottamista ja ulossulkemista ei tapahdu vain silloin, kun keskustellaan homojen oikeuksista, vaan myös pervoyhteisöjen sisällä ja välillä. Tässä numerossa julkaistut artikkelit ja muut tekstit osoittavat niitä tapoja, joilla kuulumisen politiikat aina liittyvät laajempiin valtasuhteisiin. Huolimatta siitä, että teksteissä ei välttämä̈ttä käytetä intersektionaalisuuden käsitettä, monet niistä tarjoavat huomiota siitä, kuinka yhteenkuulumisen tunne ja politiikat muotoutuvat monenlaisten erojen, kuten sukupuolen, seksuaalisuuden, rodun, luokan ja uskonnon, risteyskohdissa. Intersektionaalisuuden käsite itsessään juontaa juurensa Kimberlé Crenshaw’hin, joka alkoi käyttää käsitettä kiinnittääkseen huomiota siihen, kuinka sen paremmin feministinen kuin anti-rasistinenkaan diskurssi ei onnistunut pyrkimyksistään huolimatta ottamaan yhtä aikaa huomioon sellaisten yhdysvaltalaisnaisten kokemuksia, jotka asemoituivat yhtä aikaa sekä naisiksi että mustiksi (Crenshaw 1989). Intersektionaalinen lähestymistapa, joka huomioi samanaikaiset positioitumiset, sallii meidän moninaistaa ymmärrystämme seksuaalisista normeista, jotka usein (ja yhä uudelleen) rakentuvat toisiaan leikkaavien sosiaalisten luokittelujen avulla (ks. Kolehmainen 2012). Samaan tapaan ajatus pervoyhteisöstä monimutkaistuu, kun moninaisten erojen kertautuminen otetaan huomioon.

"Sateenkaaret pitävät sisällään eri värien koko spektrin, mutta se, kuinka monia niistä erotamme, riippuu omasta sosiaalisesta ja kielellisestä ympäristöstämme”, toteaa Nira Yuval-Davis (1996) intersektionaalisuudesta kirjoittaessaan. Luca Tainion kirja-arvio Jin Haritawornin teoksesta Queer Lovers and Hateful Others. Regenerating Violent Times and Places nostaa esiin sellaisia sosiaalisessa ympäristössä risteäviä eroja, jotka jakavat myös pervoja eri ryhmiin. Vaikka sukupuolen, seksuaalisuuden ja etnisyyden kaltaiset sosiaaliset luokittelut eivät koske vain "Toisia", vaan muokkaavat myös etuoikeutettujen ja valtaapitävien kokemuksia (Staunaes 2003), Berliinin gentrifioitumisprosessia ja sen myötä syntyviä "hyvän" ja "pahan" pervon kategorioita tutkinut Haritaworn osoittaa, että ne pervot, joihin suhtaudutaan kaikista myötämielisimmin, ovat tavallisesti valkoisia, keskiluokkaisia, nuoria ja kyvykkäitä. Näin valkoisen hyväksyttävän queerin hahmo syntyy rodullistettujen toisten kustannuksella.

Kuten Bessie Dernikos osoittaa kommenttipuheenvuorossaan, ei ole itsestään selvää, että queerit löytävät kivutta paikkansa rodullistettujen toisten

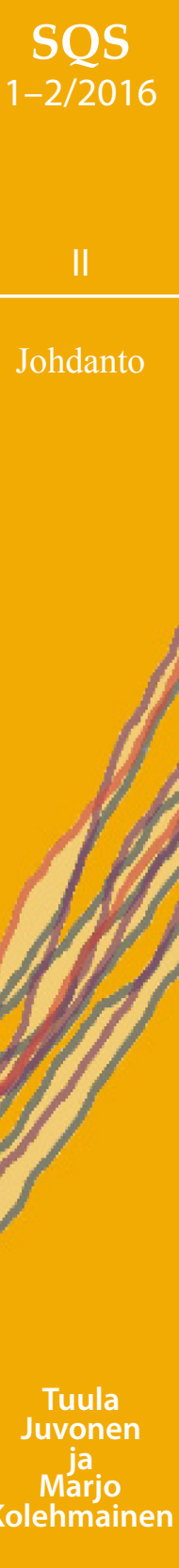


joukossa. Yhdysvalloissa kolme mustaa naista perusti \#BlackLivesMatterliikkeen vuonna 2013, vastareaktiona mustan miehen, Trayvon Martinin, ampujan vapauttamiselle murhasyytteistä. \#BLM on kehittynyt laajaksi yhteiskunnalliseksi liikkeeksi, jonka affektiivinen aktivismi liittää toisilleen vieraita ihmisiä yhteisöksi. Mutta yhtäaikaisesti samaiset affektit ovat syventäneet liikkeen sisällä rotuun, sukupuoleen ja seksuaalisuuteen liittyviä sosiaalisia rajanvetoja. Lopulta queerit identiteetit ja ruumiit - mukaan lukien liikkeen perustajajäsenten - on häivytetty liikkeestä tavalla, joka ei enää vastaa \#BLM-liikkeen alkuperäistä ajatusta kaikkien mustien elämien tärkeydestä. Dernikos esittää, että affektiivisuuden tarkastelu auttaa meitä ymmärtämään paremmin niitä kompleksisia tapoja, joilla ruumiit tulevat, tai eivät tule, merkityksellisiksi julkisuudessa.

Myös Eetu Kejonen ja Teemu Ratinen tutkivat yhtäaikaista kuulumista kahteen yhteisöön, joita yleisesti pidetään toisensa poissulkevina. Heidän analyysinsä kohteena ovat sellaiset affektiiviset ambivalenssit ja jännitteet, jotka koskevat niitä lesboiksi ja homoiksi identifioituvia ihmisiä, jotka ovat kuuluneet tai kuuluvat edelleen vanhoillislestadiolaiseen uskonyhteisöön. Heidän artikkelinsa osoittaa, kuinka affektiteoria tarjoaa hedelmällisiä välineitä tarkastella keskenään erilaisten sosiaalisten ryhmien välisiä ja sisäisiä jännitteisiä suhteita. Tässä tapauksessa yksi ryhmistä on vahvasti sitoutunut lisääntymiseen tähtäävään heteroseksuaalisen ydinperheen malliin ja toinen haastaa sen. Erityisesti silloin, kun affektin käsitettä ei typistetä vain yksilön reaktioksi, affektiivisuuden tarkastelu avaa uusia mahdollisuuksia syventää ymmärrystä kuulumisen politiikoista.

\section{Tilallisuus ja materiaalisuus yhteenkuuluvuutta luomassa}

Kuten pervohistoria osoittaa, yhteisön ja yhteenkuuluvuuden tunteen luomiseksi on usein luotava tarkoituksellisesti yhteisöllisiä tiloja. Erityisesti tilasta ja seksuaalisuudesta kiinnostunut ihmismaantiede on kes- keisesti edistänyt feminististä ja queer-tutkimuksellista otetta yhteisöjen tutkimiseen (Knopp 2007; Browne ja Ferreira 2015; Brown ja Browne 2016). Vaikka tilallisuuteen ja affekteihin keskittyvä tutkimus on edelleen harvinaista, tervetulleita avauksia on tehty esimerkiksi ilmapiirin tarkastelemisessa (Anderson 2009). Samoin materiaalisuuden ja affektiivisuuden leikkauskohtien analysointi on synnyttämässä uudenlaista queertutkimusta. Tämän numeron kirjoittajat nostavat näitä teemoja esiin erilaisissa kuulumisen konteksteissa.

Yhdysvaltalainen kommunikaatio- ja performanssitutkimuksen professori Elizabeth Whitney, joka vieraili Suomessa Fulbright-tutkijana, tutkii autoetnografisessa esseessään pervoyhteisöön kuulumisen rajoja ja mahdollisuuksia tilanteessa, jossa hän ei jakanut yhteisön kanssa samaa puhuttua kieltä. Millaisia olivat ne affektiiviset hetket, jotka auttoivat häntä ylittämään kulttuurisia rajoja ja täten luomaan edellytyksiä yhteenkuuluvuuden tunteen kokemiselle? Etsiessään pervon maailman luomisen tapoja julkisista pervoyhteisöistä, Whitneytä ohjasi se affektiivinen mielihyvä, jota hän koki tunnistaessaan queer-feministisissä tapahtumissa ja tiloissa tuttuja (ja myös outoja) olemisen ja toimimisen tapoja.

Myös kansatieteilijä Johanna Pohtinen analysoi artikkelissaan kuulumista itsevalittuun yhteisöön. Pohtinen analysoi affektiivisen kuulumisen muotoja tarinoista, joita olivat kirjoittaneet ja kertoneet ne ihmiset, jotka ovat löytäneet suomalaisten BDSM- ja fetissijärjestöjen ylläpitämät nettiyhteisöt ja järjestämät tapahtumat. Pohtinen tarkastelee tapahtumia affektiivisina vyöhykkeinä, joiden olemassaolo vaatii aktiivista työtä ja osallistumista sekä tilaisuuksien järjestäjiltä että niihin osallistuvilta vierailta. Tilaisuuksien sosiaalisuus on pitkälti materiaalisesti välittynyttä. Tilaisuuksissa vallitsevan etiketin keskeisyyden lisäksi Pohtinen painottaa vaatetuksen, symbolien ja BDSM-laitteiden merkitystä sellaisen solidaarisen ilmapiirin luomisessa, joka mahdollistaa yhteenkuulumisen tunteen ja jossa turvallisen tilan periaatteet voivat toteutua.

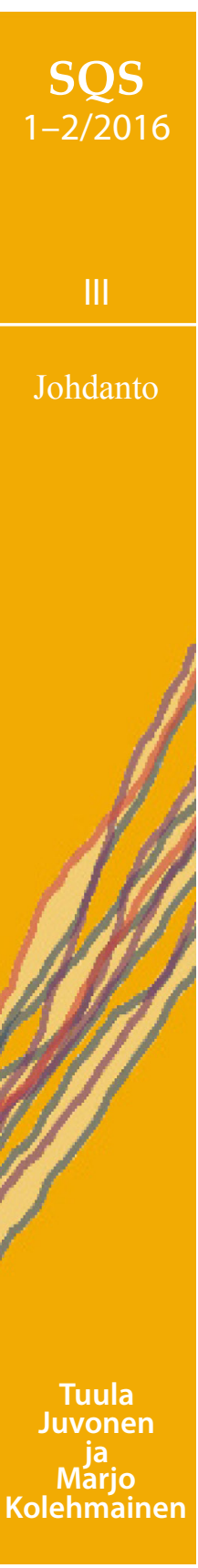


Saksalainen historioitsija Benno Gammerl jatkaa materiaalis-affektiivista analyysiä yhdistämällä siihen temporaalisuuden. Kommenttipuheenvuorossaan Gammerl käsittelee affektien ja tilallisuuden yhteen kietoutumista homomiesten yhteisöjen luomisessa. Hänen huolellinen analyysinsä saksalaisten homomiesten muistelukerronnasta osoittaa, miten 1960-luvun homobaarin ja 1980-luvun diskon kaltaisten homojen tapaamispaikkojen tilalliset järjestelyt loivat keskenään hyvin erilaiset puitteet miesten välisten affektiivisten suhteiden syntymiselle. Hän yhdistää analyysissään useita erilaisia teoreettisia lähestymistapoja ja ehdottaa, että teoreettinen moniaineksisuus voi olla hyvin hedelmällistä silloin, kun halutaan saada ote tilojen affektiivisuudesta.

\section{Ajalliset kuulumiset}

Affektiivinen kuuluminen on tietysti hyvin kontekstisidonnaista. Historioitsija Heidi Kurvisen kirja-arvostelu Sandra Hagmanin monografiasta Seitsemän outoa veljestä käy läpi niitä vastakkainasetteluja ja kuulumattomuuden tuntoja, joita homoseksuaalisuus herätti suomalaisessa yhteiskunnassa 1900-luvun alusta nykypäivään. Hagmanin kirja perustuu hänen historian alan väitöskirjaansa Seven queer brothers: narratives of forbidden male same-sex desires from modernizing Finland 1894-1971, jossa hän analysoi valikoitujen homo-oikeudenkäyntien pöytäkirjoja. Kurvinen nostaa esiin sen, kuinka Hagman onnistuu mikrohistoriallisissa tapauskertomuksissaan osoittamaan, että miesten homoseksuaalisuus on muuttunut agraari-Suomessa vielä suhteellisen harmittomana pidetystä (keskinäisen) itsetyydytyksen harjoittamisesta 1930-luvulle tultaessa kauttaaltaan medikalisoiduksi ilmiöksi. Siinä vaiheessa kun Suomi valmistautui järjestämään ensimmäiset olympialaisensa vuonna 1952, miesten homoseksuaalisuudesta oli tullut affektiivisesti vahvasti latautunut rikos. Vielä vuonna 1971 tapahtuneen homoseksuaalisten tekojen laillistamisen jälkeenkin homoseksuaalisuus säilyi Suomessa julkisten keskustelujen kiistanalaisena kysymyksenä.

Erityisesti silloin kun homoseksuaaleja on pidetty yhteiskunnan hylkiöinä, kulttuurituotteet ovat olleet tärkeässä roolissa pervojen maailmojen luomisessa tarjotessaan tilan kuvitella toisin. Arviossaan musiikintutkija Susanna Välimäen teoksesta Muutoksen musiikki. Pervoja ja ekologisia utopioita audiovisuaalisessa kulttuurissa kulttuurihistorioitsija Heta Mulari nostaa esiin niitä monia tapoja, joilla Välimäki analysoi taidetta, joka voi haastaa ja muuttaa ajatteluamme luomalla utooppisia hetkiä. Muutosvoimainen taide saattaa tulla Suomeen muualta, kuten vaikkapa Stephen Daldryn elokuva Tunnit, tai se voi syntyä paikallisesti. Kuten Mulari korostaa, pervoille taiteen utooppisten mahdollisuuksien tunnistamisen oppiminen on erityisen tärkeää, sillä heidän voi olla vaikeaa tai mahdotonta kokea affektiivista yhteenkuuluvuutta vallitsevan kulttuurin rakenteisiin.

Voimme hyvillä mielin todeta, että SQS-lehden kymmenvuotisnumero on onnistunut tuomaan yhteen kirjoittajia erilaisista sosiaalisista ja kulttuurisista piireistä, niin Suomesta kuin muualtakin. Edistämällä queerteoreettista ja affektiteoreeettista keskustelua yhteenkuulumisesta he auttavat, Yuval-Davisin sanoin, erottamaan sateenkaarten spektristä entistä useampia värejä. Sateenkaaren värit löytyvät myös kansikuvastamme. Kiitämmekin valokuvaaja Mari Hokkasta luvasta käyttää siinä hänen taideteostaan Operation Gay Over (2014) sarjasta Set and Settings.

Tässä kohden me päätoimittajat olemme iloisia voidessamme siirtää lehden toimittamisen Turun yliopistossa ja Åbo Akademissa työskenteleville kollegoillemme. He ovat jo ryhtyneet toimittamaan vuoden 2017 teemanumeroita, joiden aiheina ovat Pervot parantumiset sekä Pervo bioetiikka ja biopolitiikka. Olemme myös kiitollisia siitä, että Suomen Queer-tutki-

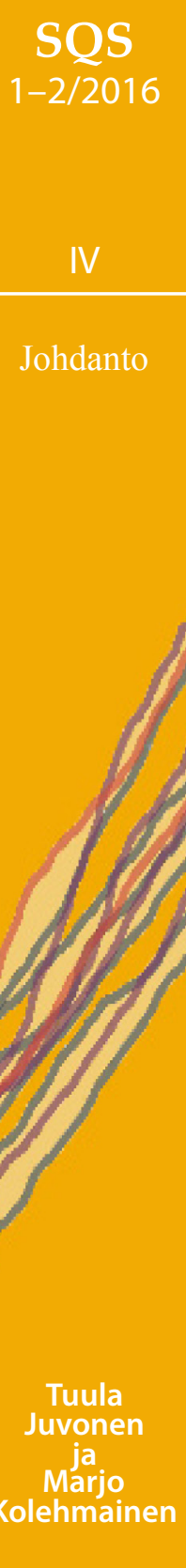


muksen Seura on onnistunut saamaan rahoitusta sekä Tieteellisten seurain valtuuskunnalta että Opetus- ja kulttuuriministeriöltä julkaisemansa $S Q S$ lehden toimituskuluihin - ensimmäistä kertaa kymmeneen vuoteen - ja voimmekin siksi suhtautua luottavaisin mielin seuran mahdollisuuksiin jatkaa queer-tutkimuksen edistämistä $S Q S$-lehden sivuilla.

\section{Lähteet}

Anderson, Ben. 2009. "Affective Atmospheres". Emotion, Space and Society 2(2009): 77-81. https://doi.org/10.1016/j.emospa.2009.08.005

Brown, Gavin ja Kath Browne (toim.). 2016. Routledge Research Companion to Geographies of Sex and Sexualities. London: Routledge.

Browne, Kath ja Eduarda Ferreira (toim.). 2015. Lesbian Geographies. Gender, Place and Power. London: Routledge.

Crenshaw, Kimberlé. 1989. "Demarginalizing the intersection of race and sex: A black feminist critique of antidiscrimination doctrine, feminist theory and antiracist politics". University of Chicago Legal Forum 14: 538-554.

Hemmings, Clare. 2012. "Affective solidarity. Feminist refexivity and political transformation". Feminist Theory 13(2): 147-161. https://doi. org $/ 10.1177 / 1464700112442643$

Juvonen, Tuula. 2015. Kaapista kaapin päälle. Homoseksuaaliset ihmiset ja heidän oikeutensa edustuksellisessa politiikassa. Vastapaino: Tampere.

Knopp, Larry. 2007. "On the Relationship Between Queer and Feminist Geographies". The Professional Geographer 59(1): 47-55. https://doi. org/10.1111/j.1467-9272.2007.00590.x

Kolehmainen, Marjo. 2012. "Tracing ambivalent norms of sexuality: Agony columns, audience responses and parody". Sexualities 15(8): 978-994. https://doi.org/10.1177/1363460712436822

Liu, Wen. 2017. "Toward a queer psychology of affect: restarting from shameful places". Subjectivity 10(1): 44-62 (julkaistu sähköisesti). https://doi. org/10.1057/s41286-016-0014-6
Lähdesmäki, Tuuli, Tuija Saresma, Kaisa Hiltunen, Saara Jäntti, Nina Sääskilahti, Antti Vallius ja Kaisa Ahvenjärvi. 2016. "Fluidity and exibility of 'belonging': Uses of the concept in contemporary research". Acta Sociologica 59(3): 233-247. https://doi.org/10.1177/0001699316633099

Seigworth, Gregory J. ja Melissa Gregg. 2010. "An inventory of shimmers". Teoksessa Affect Theory Reader, toimittaneet Gregory J. Seigworth ja Melissa Gregg. Durham ja London: Duke University Press.

Staunaes Dorthe. 2003. "Where have all the subjects gone? Bringing together the concepts of intersectionality and subjecti cation". NORA 11(2): 101-110. https://doi.org/10.1080/08038740310002950

Yuval-Davis, Nira. 1996. "Belonging and the politics of belonging". Patterns of Prejudice 40(3): 197-214. https://doi.org/10.1080/00313220600769331 